\title{
Daily leptin blunts marrow fat but does not impact bone mass in calorie-restricted mice
}

\author{
M J Devlin', D J Brooks², C Conlon'2, M van Vliet², L Louis², C J Rosen³ and \\ M L Bouxsein,2,4 \\ 1Department of Anthropology, University of Michigan, Ann Arbor, Michigan, USA \\ ${ }^{2}$ Center for Advanced Orthopedic Studies, Beth Israel Deaconess Medical Center, Boston, Massachusetts, USA \\ ${ }^{3}$ Maine Medical Center Research Institute, Scarborough, Maine, USA \\ 4Harvard Medical School, Boston, Massachusetts, USA
}

Correspondence should be addressed to M J Devlin

Email

mjdevlin@umich.edu

\begin{abstract}
Starvation induces low bone mass and high bone marrow adiposity in humans, but the underlying mechanisms are poorly understood. The adipokine leptin falls in starvation, suggesting that hypoleptinemia may be a link between negative energy balance, bone marrow fat accumulation, and impaired skeletal acquisition. In that case, treating mice with leptin during caloric restriction (CR) should reduce marrow adipose tissue (MAT) and improve bone mass. To test this hypothesis, female C57BI/6J mice were fed a $30 \%$ CR or normal (N) diet from 5 to 10 weeks of age, with daily injections of vehicle (VEH), $1 \mathrm{mg} / \mathrm{kg}$ leptin (LEP1), or $2 \mathrm{mg} / \mathrm{kg}$ leptin (LEP2) ( $N=6-8 / \mathrm{group})$. Outcomes included body mass, body fat percentage, and whole-body bone mineral density (BMD) via peripheral dual-energy X-ray absorptiometry, cortical and trabecular microarchitecture via microcomputed tomography $(\mu \mathrm{CT})$, and MAT volume via $\mu \mathrm{CT}$ of osmium tetroxide-stained bones. Overall, CR mice had lower body mass, body fat percentage, BMD, and cortical bone area fraction, but more connected trabeculae, vs $N$ mice $(P<0.05$ for all). Most significantly, although MAT was elevated in CR vs $\mathrm{N}$ overall, leptin treatment blunted MAT formation in CR mice by $50 \%$ vs VEH ( $P<0.05$ for both leptin doses). CR LEP2 mice weighed less vs CR VEH mice at 9-10 weeks of age $(P<0.05)$, but leptin treatment did not affect body fat percentage, BMD, or bone microarchitecture within either diet. These data demonstrate that once daily leptin bolus during CR inhibits bone marrow adipose expansion without affecting bone mass acquisition, suggesting that leptin has distinct effects on starvation-induced bone marrow fat formation and skeletal acquisition.
\end{abstract}

Journal of Endocrinology (2016) 229, 295-306

\section{Introduction}

Bone marrow adipose tissue (MAT) is a complex and dynamic depot that likely includes both constitutive and regulated cell populations (Devlin \& Rosen 2015,
Scheller et al. 2015). MAT accumulation is a normal component of skeletal aging in healthy individuals, but is also observed in metabolic disease, including anorexia 
nervosa, diabetes, and osteoporosis, and in skeletal unloading, including paralysis and bedrest (Yeung et al. 2005, Bredella et al. 2009, Trudel et al. 2009, Ecklund et al. 2010, Tuljapurkar et al. 2011, Baum et al. 2012, Schwartz et al. 2013). As has been widely noted, MAT may influence bone mass via interactions with adjacent osteoblasts in the marrow, as adipocytes and osteoblasts derive from a common mesenchymal progenitor (Muruganandan et al. 2009, Bianco et al. 2010). Although bone-fat interactions involve multiple hormones and growth factors, several lines of evidence suggest a role for the adipokine leptin in mediating the balance between bone and fat in the endosteal niche. First, leptin promotes the differentiation of bone marrow mesenchymal stem cells in vitro to the osteoblast rather than the adipocyte lineage, leading to the hypothesis that low leptin could lead to a relative increase in fat vs bone cells (Thomas et al. 1999). Secondly, leptin replacement in hypoleptinemia decreases skeletal fragility in animal models (Cornish et al. 2002) and increases bone formation markers in humans (Welt et al. 2004). Finally, the adipokine leptin falls in starvation, raising the possibility that hypoleptinemia contributes to marrow fat expansion and impaired skeletal acquisition (Ahima et al. 1996, Boden et al. 1996). Interactions between bone and fat may be particularly important in young, rapidly growing animals, as CR in young mice is associated with both low bone mass and high marrow adiposity (Devlin et al. 2010), whereas CR in older mice has more modest effects on bone and may not alter marrow adiposity (Hamrick et al. 2008, Tatsumi et al. 2008). Thus, here we test whether daily leptin bolus during caloric restriction (CR) reduces marrow fat and improves bone mass, using the established system of CR in young, rapidly growing mice to model human energy restriction (Devlin et al. 2010).

\section{Materials and methods}

\section{Mouse model and experimental protocol}

This study used female C57Bl/6J mice (Jackson Laboratories), studied from 5 to 10 weeks of age. Mice were weighed at baseline and assigned to groups of equivalent body mass (mean \pm s.D.). Mice were housed individually and fed a normal (N) diet ad libitum (Research Diets 12450B, 10\% kcal/fat) or a 30\% CR diet with supplemental micronutrients, which provided equivalent vitamins and minerals when fed at 70\% of caloric intake ad libitum (Research Diets D10012703, 10\% $\mathrm{kcal} / \mathrm{fat})$. Food allotments were placed into CR cages daily at 18:00 h. Body mass was measured daily on a digital scale. Body length was measured at 5 and 10 weeks of age. Mice were killed by $\mathrm{CO}_{2}$ inhalation at approximately 10:00 h. Experimental protocols were approved by the Beth Israel Deaconess Medical Center Institutional Animal Care and Use Committee.

\section{Leptin administration}

At 18:00h daily, all mice received subcutaneous injection of recombinant murine leptin (R\&D Systems) at $1 \mathrm{mg} / \mathrm{kg} /$ day (LEP1), leptin at $2 \mathrm{mg} / \mathrm{kg} /$ day (LEP2), or vehicle (VEH) ( $N=6-8 /$ group). Dosages were adjusted daily based on the body mass. We used a single late-day bolus in order to replicate the murine leptin peak that occurs in the dark cycle, during the period of greatest food intake (Ahima et al. 1996, Ahren 2000). The two doses tested, 1 or $2 \mathrm{mg} / \mathrm{kg} /$ day, correspond to roughly 20-40 $\mu$ g leptin/ day for a $20 \mathrm{~g}$ mouse and were intended to produce serum leptin levels in the physiological range of $4-8 \mathrm{ng} / \mathrm{mL}$ in C57Bl/6J mice, as previously reported (Ahima et al. 1996, Ahren 2000, Surwit et al. 2000).

\section{Peripheral dual-energy X-ray absorptiometry}

In vivo measurements of whole-body (excluding the head) bone mineral density (BMD, $\left.\mathrm{g} / \mathrm{cm}^{2}\right)$, bone mineral content (BMC, g), and body composition (\% body fat) were obtained at 5 and 10 weeks of age using peripheral dual-energy X-ray absorptiometry (pDXA, PIXImus II, GE Lunar Corporation, Madison, WI, USA), as previously described (Bouxsein et al. 2009).

\section{Serum hormones}

At the time of killing, blood was collected by cardiac puncture to measure serum leptin by ELISA (Crystal Chem, Downers Grove, IL, USA) (Devlin et al. 2010). The assay sensitivity was $0.2-12.8 \mathrm{ng} / \mathrm{mL}$.

\section{Specimen collection and preparation}

After the animals were killed, gonadal white adipose depots were dissected and weighed. Femurs, tibiae, and fifth lumbar vertebrae were excised and cleaned. The right femur and L5 vertebral body were wrapped in saline-soaked gauze and frozen at $-20^{\circ} \mathrm{C}$ for imaging analysis (Devlin et al. 2010). The left tibia was prepared for histology in $70 \%$ ethanol at $4^{\circ} \mathrm{C}$ until processing.

Published by Bioscientifica Ltd. 
The right tibia was fixed in 10\% neutral buffered formalin at $4^{\circ} \mathrm{C}$ overnight and stored in PBS for osmium tetroxide staining (Scheller et al. 2014).

\section{Trabecular and cortical bone morphology by microcomputed tomography}

Bone microarchitecture of the femoral midshaft, distal femur, and vertebral body was measured via highresolution microcomputed tomography ( $\mu$ CT40, Scanco Medical, Brüttisellen, Switzerland), as previously described (Glatt et al. 2007). Scans were acquired using a $12 \mu \mathrm{m}^{3}$ isotropic voxel size, $70 \mathrm{kVP}, 114 \mathrm{~mA}$, and $200 \mathrm{~ms}$ integration time, and were subjected to Gaussian filtration and segmentation. In the distal femur, transverse CT slices were evaluated beginning $360 \mu \mathrm{m}$ proximal to the growth plate, extending $1800 \mu \mathrm{m}$ proximally. At the femoral middiaphysis, transverse $\mu \mathrm{CT}$ slices spanning $600 \mu \mathrm{m}$ were obtained, whereas in the fifth lumbar vertebra, transverse CT slices spanning the entire vertebra, excluding growth plates, were obtained $(2400-3000 \mu \mathrm{m})$. Thresholds of 287, 708 , and $365 \mathrm{mg}$ hydroxyapatite (HA)/ $\mathrm{cm}^{3}$ were used to segment the bone from the soft tissue for the distal femur, femoral diaphysis, and vertebral body, respectively. Terminology and units followed the recommendations of the American Society for Bone and Mineral Research (Bouxsein et al. 2010).

\section{Histology and quantitative histomorphometry}

To examine bone formation rates, calcein $(15 \mathrm{mg} / \mathrm{kg})$ was injected intraperitoneally at 9 and 2 days before killing the animals. Undecalcified bones were dehydrated and cleared on a tissue processor using an alternating vacuum/ pressure cycle and, once cleared, infiltrated under vacuum for 3 days at $4^{\circ} \mathrm{C}$ with $85 \%$ methylmethacrylate (MMA) and 15\% dibutyl phthalate (DP). Following infiltration, bones were embedded in 85\% MMA, 15\% DP, and 2.5\% benzoyl peroxide (catalyst), and polymerized in a radiant heat oven at $37^{\circ} \mathrm{C}$. Once polymerized, bones were cut on a Leica 2265 microtome using a $160 \mathrm{~mm}$ D-profile tungsten-carbide knife (Dorn and Hart, Loxley, AL, USA). Unstained sections for dynamic histomorphometry were coverslipped directly with a UV inert mountant. Sections for static histomorphometry were deplastified and stained with toluidine blue (Fisher), $\mathrm{pH}$ 4.2. Microscopic analysis of static and dynamic parameters was performed using an Olympus BX40 microscope interfaced with the Osteomeasure system software and hardware (Osteometrics, Atlanta, GA, USA). All static parameters were measured on trabecular bone beginning immediately under the growth plate excluding endosteal surfaces. The field size for static parameters was $290 \times 290 \mu \mathrm{m}$, and the area measured under the growth plate extended $580 \mu \mathrm{m}$ under the growth plate where most of the trabecular bone is located. Dynamic parameters of bone formation were read similarly using a Nikon Labophot scope equipped with epifluorescence to visualize pulse-labeled calcein on the trabecular surfaces. Mineralizing surface was calculated using double labels plus half the singlelabeled surface. The field size for dynamic parameters was $350 \times 350 \mu \mathrm{m}$ and extended $700 \mu \mathrm{m}$ under the growth plate. Terminology and units followed the recommendations of the American Society for Bone and Mineral Research (Dempster et al. 2013).

\section{Osmium tetroxide staining}

Left tibiae were fixed in 10\% neutral buffered formalin at $4^{\circ} \mathrm{C}$ and decalcified in EDTA. Marrow fat was stained with a $1: 1$ solution of $2 \%$ aqueous osmium tetroxide $\left(\mathrm{OsO}_{4}\right)$ and 5\% potassium dichromate (Turello et al. 1984, Fretz et al. 2010, Scheller et al. 2014). Fat volume in the proximal and distal tibia medullary compartments was quantified using high-resolution microcomputed tomography as described previously ( $\mu$ CT40, Scanco Medical, Brüttisellen, Switzerland). For the proximal tibia, CT slices were evaluated beginning $1 \mathrm{~mm}$ below the growth plate and extending $2400 \mu \mathrm{m}$ distally. In the distal tibia, a $2400 \mu \mathrm{m}$ region was evaluated beginning at the tibiofibular junction and extending distally. The medullary canal was identified by manually tracing the endocortical border. Osmiumstained marrow fat was segmented from the adjacent marrow using a fixed threshold (1134 mg HA/ $\left.\mathrm{cm}^{3}\right)$. Adipose volume $\left(\mathrm{mm}^{3}\right)$, marrow volume $\left(\mathrm{mm}^{3}\right)$, and adipose/marrow volume fraction (\%) were measured.

\section{Statistical analyses}

Standard descriptive statistics were computed for all outcome variables, and data checked for normality. We used a General Linear Model in SPSS 22 (IBM) to test for the effect of diet, leptin, and leptin-diet interactions on body composition and bone variables. All tests were two tailed, with the significance level for major effects set at $\alpha=0.05$. If there was an overall significant effect of diet, leptin, or leptin-diet interaction for a given variable, we performed post hoc Tukey tests to identify pairwise differences. As long bone cortical cross-sectional geometry is influenced by body mass, we also adjusted femoral

Published by Bioscientifica Ltd 
cortical variables (Ct.Th, Ct.Ba, Ct.TA, Imax, Imin, pMOI) by regressing these variables against body mass and testing for significance using the residuals (Lang et al. 2005).

\section{Results}

\section{CR mice have lower body mass, body fat, serum leptin, and BMD}

Body mass was lower in CR vs $\mathrm{N}$ mice from 6 to 10 weeks of age $(P<0.0001)$, and in CR LEP2 vs CR VEH mice at $9-10$ weeks of age $(P<0.03$ for both, Fig. $1 \mathrm{~A})$. From 5 to 10 weeks of age, the total body fat mass increased by $216 \%$ in $\mathrm{N}$ mice vs $6 \%$ in CR mice $(P<0.03)$; within the CR group, fat mass in VEH mice increased by $24 \%$ despite overall weight loss, whereas LEP1 and LEP2 maintained and lost body fat, respectively $(P<0.04$, Fig. $1 \mathrm{~B})$. Lean mass decreased in CR by $22 \%$ and increased in $\mathrm{N}$ mice by $9.5 \%(P<0.001)$, Fig. 1D). At 10 weeks of age, CR mice had shorter femurs, smaller bodies, and smaller perigonadal fat pads compared with $\mathrm{N}(P<0.0001$ for all, Table 1). Fasting serum leptin, measured $16 \mathrm{~h}$ after
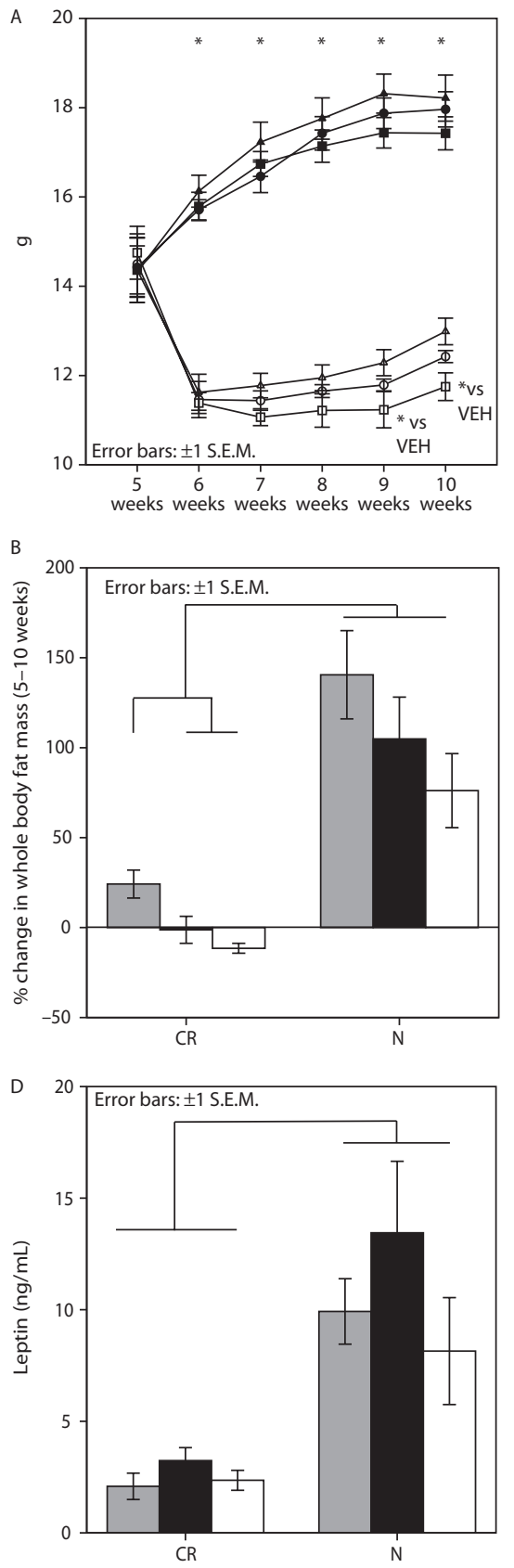
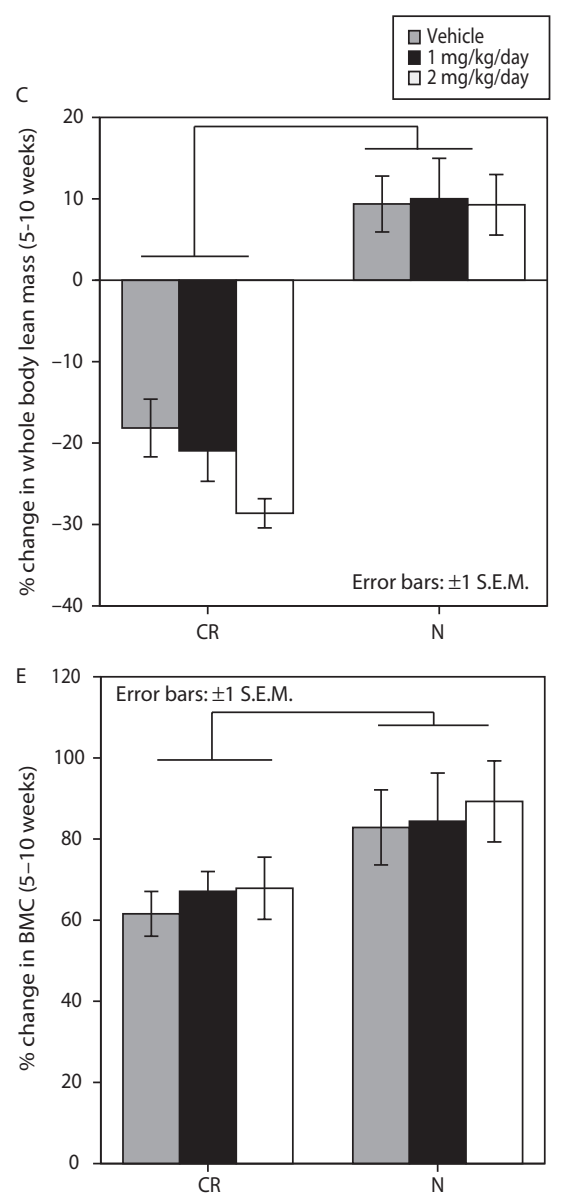

Figure 1

(A) CR weighed less than $N$ at 6-10 weeks of age, and CR LEP2 weighed less vs CR VEH at 9-10 weeks of age $(P<0.0001$ for diet at $6-10$ weeks, $P<0.03$ for dose at 9 and 10 weeks). (B) From 5 to 10 weeks of age, CR gained less body fat ( $g$ ) vs $\mathrm{N}$ $(P<0.0001$ for diet and $P=0.023$ for dose), and within CR, LEP1 and LEP2 gained less body fat vs VEH ( $P<0.04$ for both). (C) From 5 to 10 weeks of age, $C R$ lost lean mass, whereas $\mathrm{N}$ gained lean mass $(P<0.0001$ for diet) (D) At 10 weeks of age, $\mathrm{CR}$ had markedly lower leptin vs $\mathrm{N}$ irrespective of treatment group $(P<0.0001$ for diet). Daily leptin injections at 18:00 $\mathrm{h}$ did not alter fasting serum leptin $\sim 16 \mathrm{~h}$ postinjection, consistent with short half-life. (E) From 5 to 10 weeks of age, CR exhibited smaller gains in $\mathrm{BMC}$ vs $\mathrm{N}$ mice irrespective of leptin treatment ( $P=0.001$ for diet). 
the final daily injection for all mice and the final daily feeding for CR, was markedly lower in CR vs $\mathrm{N}$ mice (2.5 vs $10.5 \mathrm{ng} / \mathrm{mL}, P<0.05)$ and did not differ across leptin treatments within either diet (Fig. 1D). BMD and BMC at 10 weeks of age and the gain in BMC from 5 to 10 weeks of age were lower in CR vs $\mathrm{N}$ overall $(P<0.0004$, Fig. $1 \mathrm{E}$ and Table 1), but did not differ within either diet across leptin treatments.

\section{Leptin treatment did not affect trabecular or cortical microarchitecture}

In the distal femur trabecular bone, CR mice had lower structural model index (SMI) and higher Conn.D vs $\mathrm{N}$ $(P<0.0001$ for both), but Tb.BV/TV, Tb.N, and Tb.Th did not differ between CR and $\mathrm{N}$ mice (Fig. 2A and Table 2). There were no differences in trabecular bone variables across leptin treatments within either diet group (Fig. 2A and Table 2).

At the femoral midshaft, cortical bone cross-sectional geometric properties, including Ct.Th, Ct.BA, Ct.TA, Imax, Imin, and pMOI, were lower in CR vs $\mathrm{N}(P<0.0001$ for all, Fig. 2B, C, D and Table 2), but these differences no longer reached statistical significance after body mass adjustment (Lang et al. 2005). There were no differences in cross-sectional geometric properties across leptin treatments within either diet group.

In the fifth lumbar vertebra, N LEP2 mice had lower Tb.BV/TV vs N VEH $(P=0.033$, Table 2$)$. CR mice had higher Tb.N and Conn.D, and lower Tb.Th and Tb.Sp vs $\mathrm{N}(P<0.03$ for all, Table 2$)$, but there were no differences across leptin treatments within each diet.

\section{Leptin blunted MAT expansion in CR mice}

Daily leptin bolus during CR partially suppressed the expansion of MAT observed in CR VEH mice (Fig. 3A). In the proximal tibia, adipose volume/marrow volume as quantified by $\mu \mathrm{CT}$ scanning of bones stained with osmium tetroxide was higher in $\mathrm{CR}$ vs $\mathrm{N}$ overall $(P<0.0001)$, but $50 \%$ lower in CR LEP1 and CR LEP2 vs CR VEH $(P<0.05$ for both, Fig. 3B). Quantitative histomorphometry confirmed this pattern, with N.Ad/T.Ar higher in CR compared with $\mathrm{N}$ overall $(P<0.002)$, but lower in CR LEP1 and CR LEP2 compared with CR VEH $(P=0.046$, Table 3). BV/TV (\%) of the proximal tibia did not differ in CR vs $\mathrm{N}$ (Table 3 ). N.Ob/T.Ar and N.Ob/BS were lower in CR compared with $\mathrm{N}$ overall $(P<0.02$ for both, Table 3$)$, but did not differ across leptin treatments within either diet. Dynamic markers of bone formation, including sLS/BS, dLS/BS,
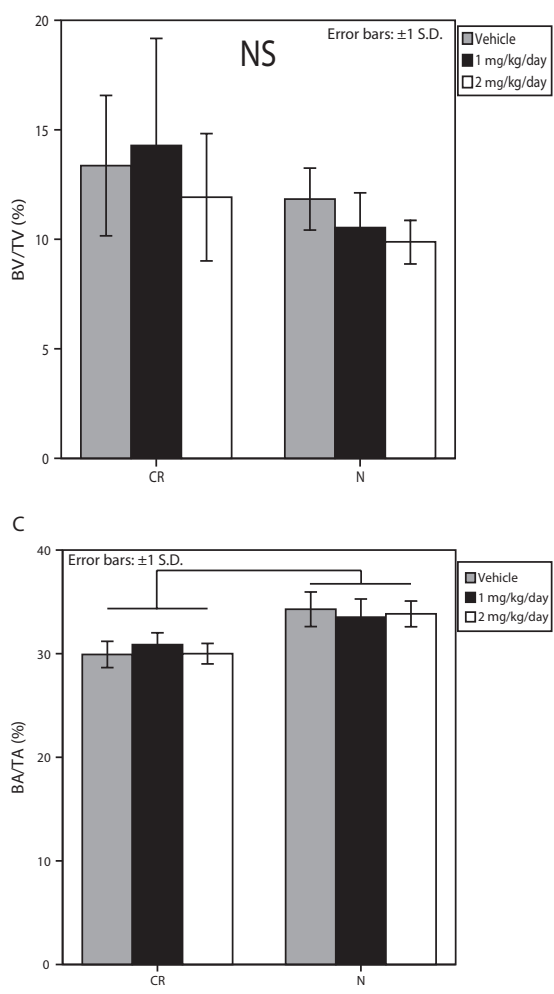

B

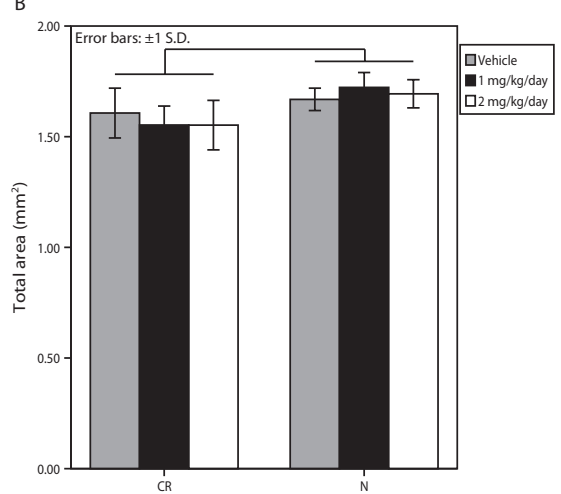

。

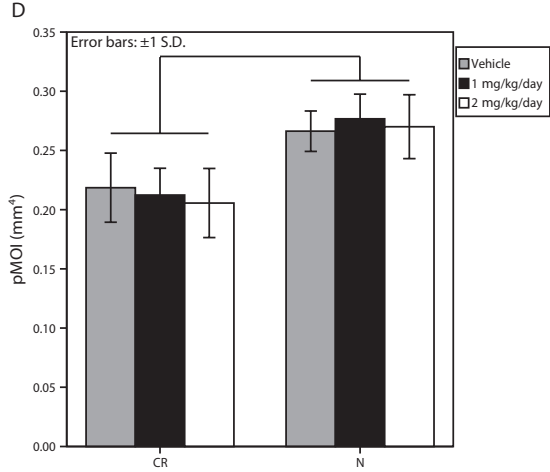

Figure 2

(A) Distal femur Tb.BV/TV (\%) did not differ by diet or by leptin treatment. (B) Ct.TA $\left(\mathrm{mm}^{2}\right)$, (C) Ct.BA/TA (\%), and (D) Ct.pMOI were lower in CR vs $\mathrm{N}$ before body mass adjustment $(P<0.0001$ for diet), but did not differ by leptin treatment. http://joe.endocrinology-journals.org DOI: 10.1530/JOE-15-0473
C) 2016 Society for Endocrinology Printed in Great Britain 


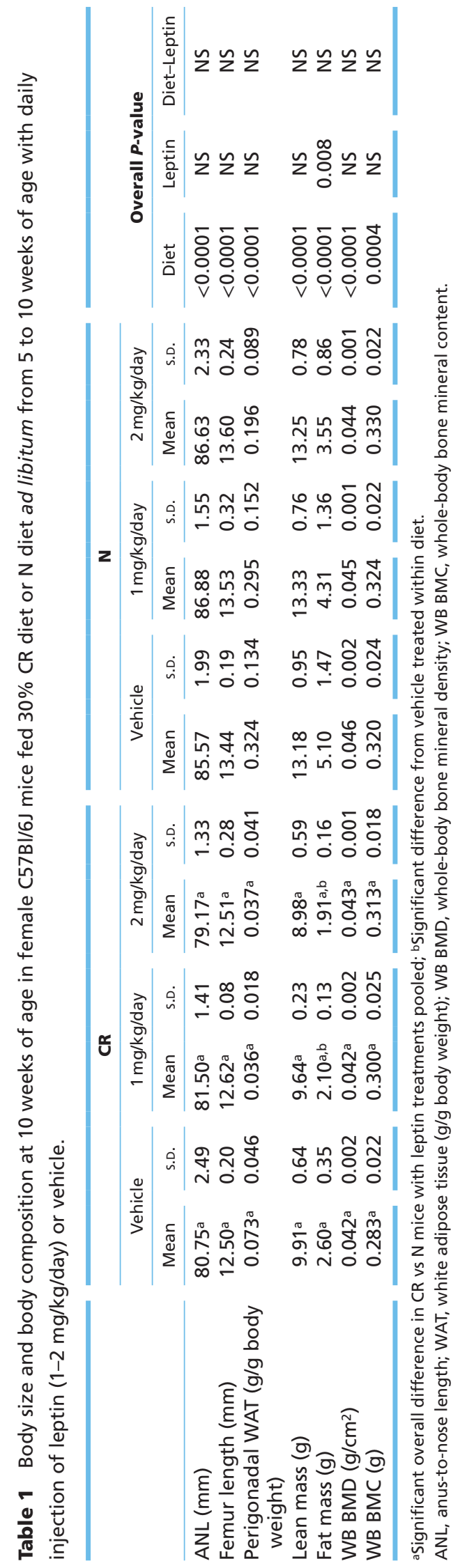

http://joe.endocrinology-journals.org DOI: 10.1530/JOE-15-0473 (c) 2016 Society for Endocrinology Printed in Great Britain

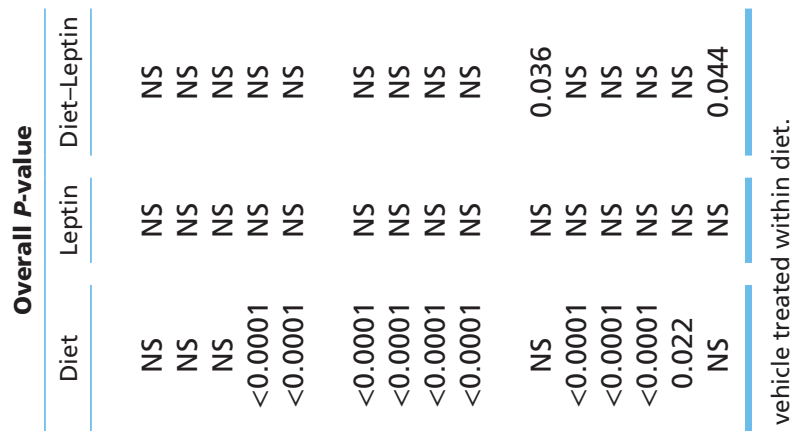

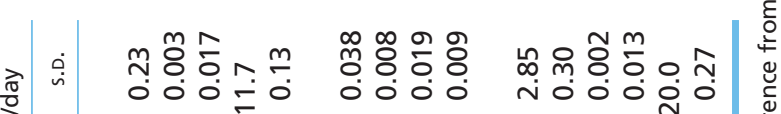
की no.

产

i

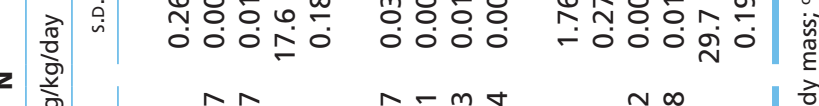

क्ष

पूर

|

焉

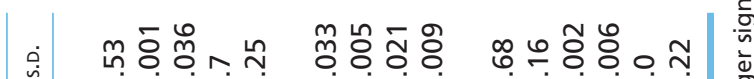

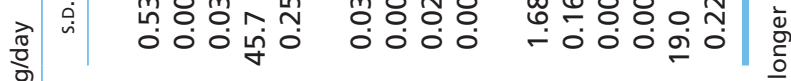

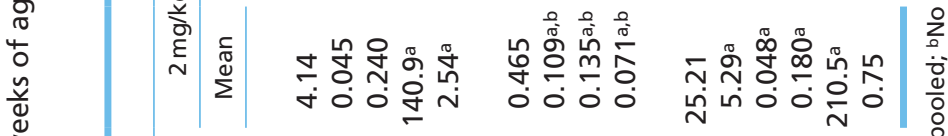

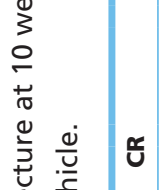

|

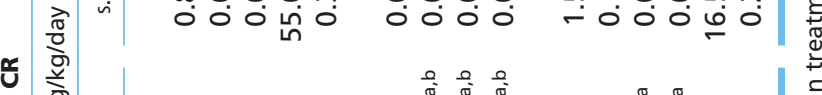

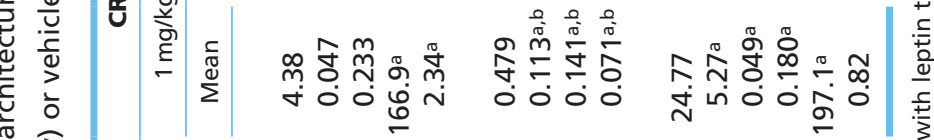

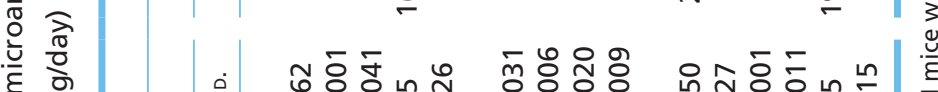

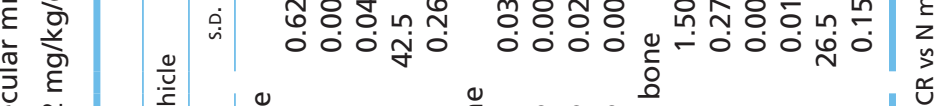

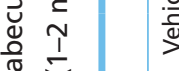

焉空

宁

त्

范

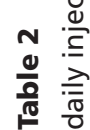

Published by Bioscientifica Ltd. 
A

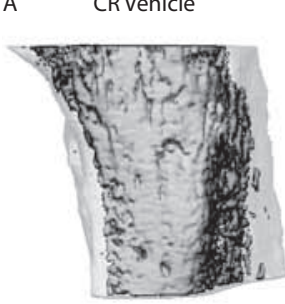

CR Leptin
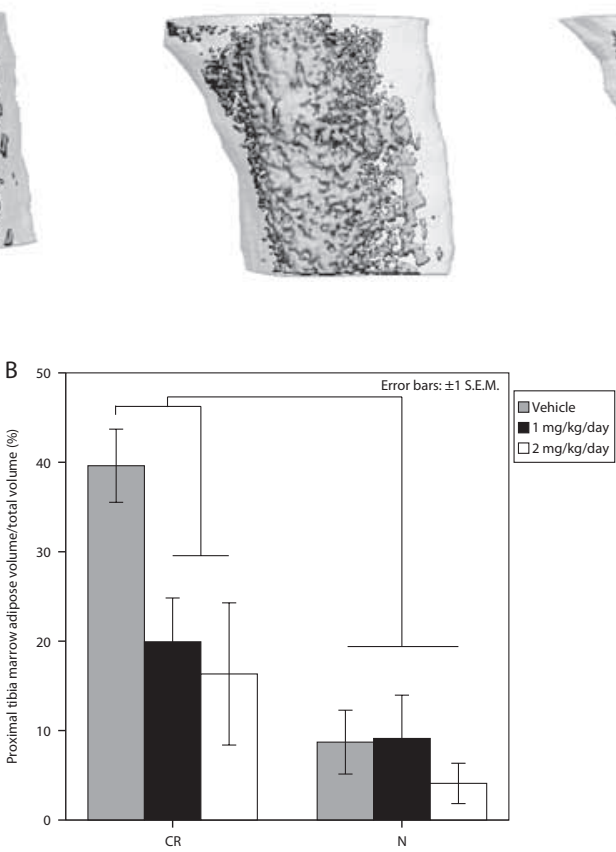

N Vehicle

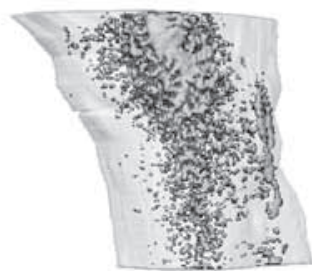

Figure 3

(A) Leptin treatment during CR blunted MAT expansion compared with $\mathrm{CR} V \mathrm{VH}$, as indicated by extent of $\mathrm{OSO}_{4}$ staining (shown in dark gray). (B) Proximal tibia adipose volume/marrow volume in $\mathrm{OsO}_{4}$ stained bones was higher in $\mathrm{CR}$ vs $\mathrm{N}$, and $50 \%$ lower in CR LEP1 and CR LEP2 vs CR VEH $(P<0.0001$ for diet, $P=0.016$ for dose).
MAR, MS/BS, and BFR/BS, were 36-108\% lower in CR vs N overall, but did not differ across leptin treatments within either diet $(P<0.0001$ for all, Table 3$)$.

\section{Discussion}

In this study, we tested the effects of a daily leptin bolus of $1-2 \mathrm{mg} / \mathrm{kg} /$ day during CR in young, rapidly growing mice. We hypothesized that leptin treatment would attenuate the deleterious effects of CR on bone mass and bone marrow adiposity. To test this hypothesis, we evaluated BMD, cortical and trabecular bone properties, and marrow adipose expansion in female C57Bl/6J mice from 5 to 10 weeks of age. VEH-treated CR mice lost body mass, particularly lean mass, and exhibited smaller gains in body fat and BMD during the experiment compared with VEH-treated N controls. The skeletal phenotype of VEHtreated CR mice included lower whole-body BMD and lower cross-sectional geometric properties in the midshaft femur before adjustment for body mass, with no effects observed on the trabecular bone microarchitecture. Static and dynamic histomorphometry in the proximal tibia showed that the bones of CR mice had fewer osteoblasts, more adipocytes, and lower indices of bone formation compared with $\mathrm{N}$ mice.

Our first hypothesis, that leptin treatment during CR would increase bone mass acquisition, was not supported by the data. Daily leptin injection of $1-2 \mathrm{mg} / \mathrm{kg} /$ day did not increase BMD, alter cortical or trabecular bone architecture, or increase bone formation indices in $\mathrm{CR}$ mice, nor did it alter skeletal phenotype in $\mathrm{N}$ mice fed ad libitum. There was support for our second hypothesis that leptin would blunt the increase in marrow adiposity observed with exposure to a CR diet. Specifically, VEHtreated CR mice had a fourfold increase in marrow adiposity compared to VEH-treated $\mathrm{N}$ mice. Leptin treatment reduced the CR-induced expansion of marrow adipose in the proximal tibia by 50\%, although the MAT volume was still markedly higher than in $\mathrm{N}$ mice. These data support the hypothesis that hypoleptinemia contributes to MAT expansion during CR.

\section{Comparison to prior studies of leptin and bone}

Hypoleptinemia is associated with low bone mass in humans with anorexia nervosa (Hebebrand et al. 1997) and in animal models (Devlin et al. 2010). The skeletal effects of leptin are complex and include both central nervous system pathways via the hypothalamus and peripheral pathways involving direct effects of leptin on bone cells. Studies in wild-type mice reported lower trabecular bone volume fraction in the vertebra following intracerebroventricular (ICV) leptin infusion (Ducy et al. 2000, Takeda et al. 2002, Sato et al. 2007).

Published by Bioscientifica Ltd. 


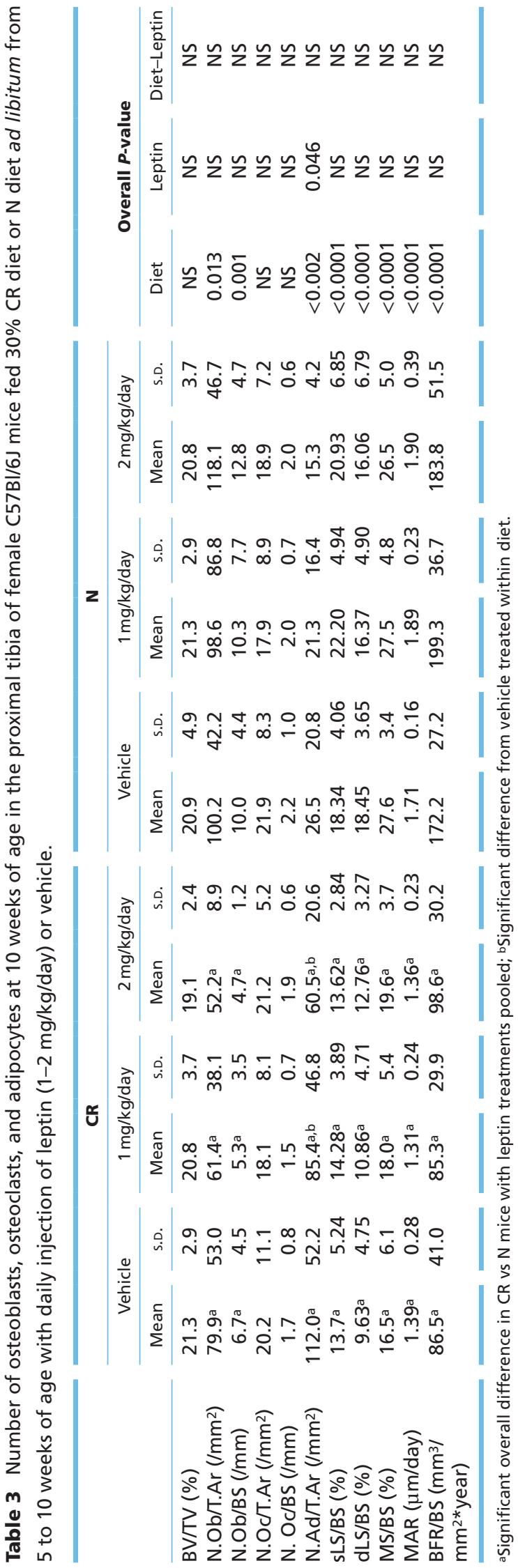

http://joe.endocrinology-journals.org DOI: 10.1530/JOE-15-0473
(C) 2016 Society for Endocrinology Printed in Great Britain
By contrast, in the hypoleptinemic ob/ob mouse, ICV leptin improved bone formation and reduced MAT (Hamrick et al. 2007, Bartell et al. 2011), and hypothalamic leptin gene therapy increased femur length, total femur volume, and circulating osteocalcin but reduced trabecular bone volume in the distal femur and vertebra (Iwaniec et al. 2007, 2009, Kalra et al. 2009).

The peripheral or direct effects of leptin on bone are similarly heterogeneous. The finding that leptin receptor (Lepr) deletion in osteoblasts had no effect on murine skeletal phenotype implied little direct effect of leptin on osteoblasts (Shi et al. 2008). However, Zhou and coworkers recently reported that bone marrow mesenchymal stromal cells expressing the leptin receptor can differentiate into the bone, cartilage, and adipocytes, both in vivo and in vitro, and showed by fate mapping that in adult bone marrow, these leptin receptor-positive cells represent the primary source of bone and adipocytes (Zhou et al. 2014). In vitro, leptin increased osteoblast and chondrocyte proliferation, and inhibited osteoclast formation, and in adult male wildtype mice, peripheral injection of leptin $(43 \mu \mathrm{g} /$ day $)$ increased the bone strength, suggesting anabolic effects of leptin on cortical bone (Cornish et al. 2002). Leptin treatment in mice subjected to $40 \%$ CR prevented the CR-induced decrease in longitudinal bone growth (GatYablonski et al. 2004). In the $o b / o b$ mouse, peripheral leptin improved bone mass and bone formation rate and reduced MAT (Steppan et al. 2000, Hamrick et al. 2005, Turner et al. 2013). Continuous infusion of supraphysiological leptin doses (100 or $200 \mathrm{mg} /$ day) in female rats increased serum leptin by 14 - to 33 -fold and decreased body mass, but while the $100 \mathrm{mg}$ /day dose led to lower whole-body BMD, femoral cortical bone volume, femoral bone strength, and femoral polar moment of inertia, the higher dose did not, suggesting that bone loss was prevented despite weight loss (Stunes et al. 2012). High-dose leptin $(2.5 \mathrm{mg} / \mathrm{kg} 2 \times /$ day $)$ also prevented the fasting-induced decrease in osteocalcin in BALB/c males (Goldstone et al. 2002).

Taken together, these studies suggest that both centrally and peripherally administered leptin can be anabolic, neutral, or deleterious to bone mass. Although some of this variability likely reflects the different background strains, dosages, routes of administration, sexes, and ages at onset and offset of treatment used in different studies, it appears that in general, leptin is anabolic to bone in hypoleptinemic animals, but has less effect in leptinreplete animals unless delivered at supraphysiological doses (Kawai et al. 2009). In this study, the lack of skeletal

Published by Bioscientifica Ltd. 
effects of leptin likely reflects an insufficient dose and/or route of administration (see below).

\section{Comparison to prior studies of leptin and MAT}

Previous studies have demonstrated that leptin decreases MAT in genetic models of hypoleptinemia (Hamrick et al. 2005, Turner et al. 2013) and in leptin-replete wild-type rats (Hamrick et al. 2007). Humans with anorexia nervosa similarly exhibited attenuation of marrow adiposity with weight recovery (Fazeli et al. 2012). The inverse relationship of leptin and marrow adiposity may reflect direct as well as indirect mechanisms. Bone marrow adipocytes, osteoblasts, and myocytes derive from a common mesenchymal progenitor (Bianco et al. 2008, 2010, Zhou et al. 2014), and leptin directly promotes osteoblastogenesis and suppresses adipogenesis, such that hypoleptinemia could both increase marrow adiposity and decrease bone mass (Muruganandan et al. 2009, Evans et al. 2011). In addition, there may be cross talk between leptin, estrogen, and the GH-IGF1 axis, both of which are suppressed in CR in humans and animal models (Mobbs et al. 2001, Devlin et al. 2010, Misra \& Klibanski 2011). Postmenopausal estrogen deficiency in women is associated with MAT expansion, and estrogen replacement increases serum leptin and decreases marrow adiposity (Syed et al. 2008, Limonard et al. 2015). GH deficiency leads to expansion of MAT that is attenuated by GH replacement in dwarf $(d w / d w)$ rats (Gevers et al. 2002) and in hypophysectomized mice and rats (Menagh et al. 2010). In humans, vertebral MAT is inversely associated with circulating IGF1 (Bredella et al. 2010). Thus, in addition to direct action on osteoblast and adipocyte progenitors, leptin replacement during CR may decrease MAT by increasing $\mathrm{GH}$ and/or estrogen levels (Casanueva \& Dieguez 1999, Ahima et al. 2000, Chou et al. 2011), a possibility that should be tested in future studies. Another possibility is that glucocorticoids are key to MAT expansion. A new study of male and female C57BL/6J mice exposed to CR from 9 to 15 weeks found CR-induced hypoleptinemia and loss of WAT in males but not females (Cawthorn et al. 2016). Further, CR in rabbits from 6-13 or 15-22 weeks of age induced hypoleptinemia, lower bone mass, and loss of WAT, but not MAT expansion (Cawthorn et al. 2016). These intriguing findings demonstrate that bone loss, hypoleptinemia, and MAT expansion are not inevitable consequences of CR and may occur independently of one another depending on age, sex, and species. The authors suggest that a CR-induced increase in glucocorticoids observed in mice but not rabbits may be the driver of MAT expansion (Cawthorn et al. 2016).

\section{Limitations and future directions}

Our study has several limitations that should be addressed in future work. First, and most importantly, we used a leptin dosage of $1-2 \mathrm{mg} / \mathrm{kg} / \mathrm{day}$, or $20-40 \mu \mathrm{g}$ leptin/day, in a single daily bolus timed to coincide with the nocturnal peak in leptin following food intake (Ahima et al. 1996, Ahren 2000). This dosage and administration route may have induced transiently normal or high leptin levels but were insufficient to achieve sustained normalization of serum leptin in CR mice, as measured $16 \mathrm{~h}$ following injection. Leptin has a short half-life, and it is clear that higher doses given via multiple daily injections or continuous leptin infusion will be needed to fully correct hypoleptinemia in CR animals. For example, daily leptin injection at $8 \mu \mathrm{g} / \mathrm{g}$ was sufficient to reverse inhibition of longitudinal bone growth in CR, although serum leptin levels were not reported (Gat-Yablonski et al. 2004). Secondly, these data reflect only female mice, and there may be sex differences in the response to CR and/or effects of leptin on the bone and MAT. Thirdly, we studied mice during a single interval of 5-10 weeks of age. The effects of CR on the bone mass show marked age-related variation (Hamrick et al. 2008, Tatsumi et al. 2008, Devlin et al. 2010), and its effects on leptin levels and MAT expansion may also vary with age. Fourthly, here we focused solely on leptin and did not assess other bone-active hormones such as adiponectin or osteocalcin that are known to change in CR (Cawthorn et al. 2014) and to contribute to skeletal homeostasis in humans (Gravenstein et al. 2011). Finally, we studied only a single strain, C57Bl/6J, and it is clear that the relationships between the bone mass and MAT vary tremendously across strains (Fazeli et al. 2013, Scheller et al. 2015). Thus, future studies should include males; incorporate different ages and durations of CR exposure; consider additional hormonal factors; and include strains such as $\mathrm{C} 3 \mathrm{H} / \mathrm{HeJ}$, which exhibits both high bone mass and high MAT on diet ad libitum (Motyl \& Rosen 2011, Scheller et al. 2015).

\section{Conclusion}

In this study, we found that once daily leptin treatment of $1-2 \mathrm{mg} / \mathrm{kg} /$ day is sufficient to blunt CR-induced MAT expansion, but does not alter the serum leptin level or cortical or trabecular bone architecture or bone formation

Published by Bioscientifica Ltd. 
in young female C57Bl/6J mice. These results suggest that bone MAT and bone tissue may have different sensitivities to small and/or transient changes in circulating leptin level. Such subtle changes may be sufficient to reduce MAT without inducing a corresponding increase in bone mass during $\mathrm{CR}$ in young female mice.

\section{Declaration of interest}

The authors declare that there is no conflict of interest that could be perceived as prejudicing the impartiality of the research reported.

\section{Funding}

This work was supported by the National Institutes of Health (RC1AR058389, R24DK092759, S10RR017868, and F32HD060419).

\section{Acknowledgments}

The authors thank Mark Horowitz, Yale School of Medicine, New Haven, Connecticut, for assistance with bone histomorphometry and osmium tetroxide staining.

\section{References}

Ahima RS, Prabakaran D, Mantzoros C, Qu D, Lowell B, Maratos-Flier E \& Flier JS 1996 Role of leptin in the neuroendocrine response to fasting. Nature 382 250-252. (doi:10.1038/382250a0)

Ahima RS, Saper CB, Flier JS \& Elmquist JK 2000 Leptin regulation of neuroendocrine systems. Frontiers in Neuroendocrinology 21 263-307. (doi:10.1006/frne.2000.0197)

Ahren B 2000 Diurnal variation in circulating leptin is dependent on gender, food intake and circulating insulin in mice. Acta Physiologica Scandinavica 169 325-331. (doi:10.1046/j.1365-201x.2000.00746.x)

Bartell SM, Rayalam S, Ambati S, Gaddam DR, Hartzell DL, Hamrick M, She JX, Della-Fera MA \& Baile CA 2011 Central (ICV) leptin injection increases bone formation, bone mineral density, muscle mass, serum IGF-1, and the expression of osteogenic genes in leptin-deficient ob/ob mice. Journal of Bone and Mineral Research 26 1710-1720. (doi:10.1002/jbmr.406)

Baum T, Yap SP, Karampinos DC, Nardo L, Kuo D, Burghardt AJ, Masharani UB, Schwartz AV, Li X \& Link TM 2012 Does vertebral bone marrow fat content correlate with abdominal adipose tissue, lumbar spine bone mineral density, and blood biomarkers in women with type 2 diabetes mellitus? Journal of Magnetic Resonance Imaging 35 117-124. (doi:10.1002/jmri.22757)

Bianco P, Robey PG \& Simmons PJ 2008 Mesenchymal stem cells: revisiting history, concepts, and assays. Cell Stem Cell 2 313-319. (doi:10.1016/j.stem.2008.03.002)

Bianco P, Robey PG, Saggio I \& Riminucci M 2010 'Mesenchymal' stem cells in human bone marrow (skeletal stem cells): a critical discussion of their nature, identity, and significance in incurable skeletal disease. Human Gene Therapy 21 1057-1066. (doi:10.1089/ hum.2010.136)

Boden G, Chen X, Mozzoli M \& Ryan I 1996 Effect of fasting on serum leptin in normal human subjects. Journal of Clinical Endocrinology and Metabolism 81 3419-3423. (doi:10.1210/jcem.81.9.8784108)

Bouxsein ML, Devlin MJ, Glatt V, Dhillon H, Pierroz DD \& Ferrari SL 2009 Mice lacking beta-adrenergic receptors have increased bone mass, but are not protected from deleterious skeletal effects of ovariectomy. Endocrinology 150 144-152. (doi:10.1210/en.2008-0843)

Bouxsein ML, Boyd SK, Christiansen BA, Guldberg RE, Jepsen KJ \& Muller R 2010 Guidelines for assessment of bone microstructure in rodents using micro-computed tomography. Journal of Bone and Mineral Research 25 1468-1486. (doi:10.1002/jbmr.141)

Bredella MA, Fazeli PK, Miller KK, Misra M, Torriani M, Thomas BJ, Ghomi RH, Rosen CJ \& Klibanski A 2009 Increased bone marrow fat in anorexia nervosa. Journal of Clinical Endocrinology and Metabolism 94 2129-2136. (doi:10.1210/jc.2008-2532)

Bredella MA, Torriani M, Ghomi RH, Thomas BJ, Brick DJ, Gerweck AV, Rosen CJ, Klibanski A \& Miller KK 2010 Vertebral bone marrow fat is positively associated with visceral fat and inversely associated with IGF-1 in obese women. Obesity 19 49-53. (doi:10.1038/oby.2010.106)

Casanueva FF \& Dieguez C 1999 Neuroendocrine regulation and actions of leptin. Frontiers in Neuroendocrinology 20 317-363. (doi:10.1006/ frne.1999.0187)

Cawthorn WP, Scheller EL, Learman BS, Parlee SD, Simon BR, Mori H, Ning X, Bree AJ, Schell B, Broome DT, et al. 2014 Bone marrow adipose tissue is an endocrine organ that contributes to increased circulating adiponectin during caloric restriction. Cell Metabolism 20 368-375. (doi:10.1016/j.cmet.2014.06.003)

Cawthorn WP, Scheller EL, Parlee SD, Pham HA, Learman BS, Redshaw CM, Sulston RJ, Burr AA, Das AK, Simon BR, et al. 2016 Expansion of bone marrow adipose tissue during caloric restriction is associated with increased circulating glucocorticoids and not with hypoleptinemia. Endocrinology 157 508-521. (doi:10.1210/en.20151477)

Chou SH, Chamberland JP, Liu X, Matarese G, Gao C, Stefanakis R, Brinkoetter MT, Gong H, Arampatzi K \& Mantzoros CS 2011 Leptin is an effective treatment for hypothalamic amenorrhea. PNAS $\mathbf{1 0 8}$ 6585-6590. (doi:10.1073/pnas.1015674108)

Cornish J, Callon KE, Bava U, Lin C, Naot D, Hill BL, Grey AB, Broom N, Myers DE, Nicholson GC, et al. 2002 Leptin directly regulates bone cell function in vitro and reduces bone fragility in vivo. Journal of Endocrinology 175 405-415. (doi:10.1677/joe.0.1750405)

Dempster DW, Compston JE, Drezner MK, Glorieux FH, Kanis JA, Malluche H, Meunier PJ, Ott SM, Recker RR \& Parfitt AM 2013 Standardized nomenclature, symbols, and units for bone histomorphometry: a 2012 update of the report of the ASBMR Histomorphometry Nomenclature Committee. Journal of Bone and Mineral Research 28 2-17. (doi:10.1002/jbmr.1805)

Devlin MJ \& Rosen CJ 2015 The bone-fat interface: basic and clinical implications of marrow adiposity. Lancet Diabetes \& Endocrinology 3 141-147. (doi:10.1016/S2213-8587(14)70007-5)

Devlin MJ, Cloutier AM, Thomas NA, Panus DA, Lotinun S, Pinz I, Baron R, Rosen CJ \& Bouxsein ML 2010 Caloric restriction leads to high marrow adiposity and low bone mass in growing mice. Journal of Bone and Mineral Research 25 2078-2088. (doi:10.1002/jbmr.82)

Ducy P, Amling M, Takeda S, Priemel M, Schilling AF, Beil FT, Shen J, Vinson C, Rueger JM \& Karsenty G 2000 Leptin inhibits bone formation through a hypothalamic relay: a central control of bone mass. Cell 100 197-207. (doi:10.1016/S0092-8674(00)81558-5)

Ecklund K, Vajapeyam S, Feldman HA, Buzney CD, Mulkern RV, Kleinman PK, Rosen CJ \& Gordon CM 2010 Bone marrow changes in adolescent girls with anorexia nervosa. Journal of Bone and Mineral Research 25 298-304. (doi:10.1359/jbmr.090805)

Evans BA, Bull MJ, Kench RC, Fox RE, Morgan LD, Stevenson AE, Gevers EF, Perry MJ \& Wells T 2011 The influence of leptin on trabecular architecture and marrow adiposity in GH-deficient rats. Journal of Endocrinology 208 69-79. (doi:10.1677/JOE-10-0178)

Fazeli PK, Bredella MA, Freedman L, Thomas BJ, Breggia A, Meenaghan E, Rosen CJ \& Klibanski A 2012 Marrow fat and preadipocyte factor-1 levels decrease with recovery in women with anorexia nervosa. Journal of Bone and Mineral Research 27 1864-1871. (doi:10.1002/ jbmr.1640) 
Fazeli PK, Horowitz MC, MacDougald OA, Scheller EL, Rodeheffer MS, Rosen CJ \& Klibanski A 2013 Marrow fat and bone - new perspectives. Journal of Clinical Endocrinology and Metabolism 98 935-945. (doi:10.1210/jc.2012-3634)

Fretz JA, Nelson T, Xi Y, Adams DJ, Rosen CJ \& Horowitz MC 2010 Altered metabolism and lipodystrophy in the early B-cell factor 1-deficient mouse. Endocrinology 151 1611-1621. (doi:10.1210/ en.2009-0987)

Gat-Yablonski G, Ben-Ari T, Shtaif B, Potievsky O, Moran O, Eshet R, Maor G, Segev Y \& Phillip M 2004 Leptin reverses the inhibitory effect of caloric restriction on longitudinal growth. Endocrinology 145 343-350. (doi:10.1210/en.2003-0910)

Gevers EF, Loveridge N \& Robinson IC 2002 Bone marrow adipocytes: a neglected target tissue for growth hormone. Endocrinology 143 4065-4073. (doi:10.1210/en.2002-220428)

Glatt V, Canalis E, Stadmeyer L \& Bouxsein ML 2007 Age-related changes in trabecular architecture differ in female and male C57BL/6J mice. Journal of Bone and Mineral Research 22 1197-1207. (doi:10.1359/ jbmr.070507)

Goldstone AP, Howard JK, Lord GM, Ghatei MA, Gardiner JV, Wang ZL, Wang RM, Girgis SI, Bailey CJ \& Bloom SR 2002 Leptin prevents the fall in plasma osteocalcin during starvation in male mice. Biochemical and Biophysical Research Communications 295 475-481. (doi:10.1016/ S0006-291X(02)00697-6)

Gravenstein KS, Napora JK, Short RG, Ramachandran R, Carlson OD, Metter EJ, Ferrucci L, Egan JM \& Chia CW 2011 Cross-sectional evidence of a signaling pathway from bone homeostasis to glucose metabolism. Journal of Clinical Endocrinology and Metabolism 96 E884-E890. (doi:10.1210/jc.2010-2589)

Hamrick MW, Della-Fera MA, Choi YH, Pennington C, Hartzell D \& Baile CA 2005 Leptin treatment induces loss of bone marrow adipocytes and increases bone formation in leptin-deficient ob/ob mice. Journal of Bone and Mineral Research 20 994-1001. (doi:10.1359/ JBMR.050103)

Hamrick MW, Della Fera MA, Choi YH, Hartzell D, Pennington C \& Baile CA 2007 Injections of leptin into rat ventromedial hypothalamus increase adipocyte apoptosis in peripheral fat and in bone marrow. Cell Tissue Research 327 133-141. (doi:10.1007/s00441-006-0312-3)

Hamrick MW, Ding KH, Ponnala S, Ferrari SL \& Isales CM 2008 Caloric restriction decreases cortical bone mass but spares trabecular bone in the mouse skeleton: implications for the regulation of bone mass by body weight. Journal of Bone and Mineral Research 23 870-878. (doi:10.1359/jbmr.080213)

Hebebrand J, Blum WF, Barth N, Coners H, Englaro P, Juul A, Ziegler A, Warnke A, Rascher W \& Remschmidt H 1997 Leptin levels in patients with anorexia nervosa are reduced in the acute stage and elevated upon short-term weight restoration. Molecular Psychiatry 2 330-334. (doi:10.1038/sj.mp.4000282)

Iwaniec UT, Boghossian S, Lapke PD, Turner RT \& Kalra SP 2007 Central leptin gene therapy corrects skeletal abnormalities in leptin-deficient ob/ob mice. Peptides 28 1012-1019. (doi:10.1016/j. peptides.2007.02.001)

Iwaniec UT, Dube MG, Boghossian S, Song H, Helferich WG, Turner RT \& Kalra SP 2009 Body mass influences cortical bone mass independent of leptin signaling. Bone 44 404-412. (doi:10.1016/j. bone.2008.10.058)

Kalra SP, Dube MG \& Iwaniec UT 2009 Leptin increases osteoblastspecific osteocalcin release through a hypothalamic relay. Peptides $\mathbf{3 0}$ 967-973. (doi:10.1016/j.peptides.2009.01.020)

Kawai M, Devlin MJ \& Rosen CJ 2009 Fat targets for skeletal health. Nature Reviews Rheumatology 5 365-372. (doi:10.1038/ nrrheum.2009.102)

Lang DH, Sharkey NA, Lionikas A, Mack HA, Larsson L, Vogler GP, Vandenbergh DJ, Blizard DA, Stout JT, Stitt JP, et al. 2005 Adjusting data to body size: a comparison of methods as applied to quantitative http://joe.endocrinology-journals.org

DOI: $10.1530 / J O E-15-0473$
(C) 2016 Society for Endocrinology Printed in Great Britain trait loci analysis of musculoskeletal phenotypes. Journal of Bone and Mineral Research 20 748-757. (doi:10.1359/JBMR.041224)

Limonard EJ, Veldhuis-Vlug AG, van Dussen L, Runge JH, Tanck MW, Endert E, Heijboer AC, Fliers E, Hollak CE, Akkerman EM, et al. 2015 Short-term effect of estrogen on human bone marrow Fat. Journal of Bone and Mineral Research 30 2058-2066. (doi:10.1002/ jbmr.2557)

Menagh PJ, Turner RT, Jump DB, Wong CP, Lowry MB, Yakar S, Rosen CJ \& Iwaniec UT 2010 Growth hormone regulates the balance between bone formation and bone marrow adiposity. Journal of Bone and Mineral Research 25 757-768. (doi:10.1359/jbmr.091015)

Misra M \& Klibanski A 2011 Bone health in anorexia nervosa. Current Opinion in Endocrinology, Diabetes and Obesity 18 376-382. (doi:10.1097/MED.0b013e32834b4bdc)

Mobbs CV, Bray GA, Atkinson RL, Bartke A, Finch CE, Maratos-Flier E, Crawley JN \& Nelson JF 2001 Neuroendocrine and pharmacological manipulations to assess how caloric restriction increases life span. Journals of Gerontology Series A: Biological Sciences and Medical Sciences 56 34-44. (doi:10.1093/gerona/56.suppl_1.34)

Motyl KJ \& Rosen CJ 2011 Temperatures rising: brown fat and bone. Discovery Medicine 11 179-185.

Muruganandan S, Roman AA \& Sinal CJ 2009 Adipocyte differentiation of bone marrow-derived mesenchymal stem cells: cross talk with the osteoblastogenic program. Cellular and Molecular Life Sciences $6 \mathbf{6}$ 236-253. (doi:10.1007/s00018-008-8429-z)

Sato S, Hanada R, Kimura A, Abe T, Matsumoto T, Iwasaki M, Inose H, Ida T, Mieda M, Takeuchi Y, et al. 2007 Central control of bone remodeling by neuromedin U. Nature Medicine 13 1234-1240. (doi:10.1038/nm1640)

Scheller EL, Troiano N, Vanhoutan JN, Bouxsein MA, Fretz JA, Xi Y, Nelson T, Katz G, Berry R, Church CD, et al. 2014 Use of osmium tetroxide staining with microcomputerized tomography to visualize and quantify bone marrow adipose tissue in vivo. Methods in Enzymology 537 123-139. (doi:10.1016/B978-0-12411619-1.00007-0)

Scheller EL, Doucette CR, Learman BS, Cawthorn WP, Khandaker S, Schell B, Wu B, Ding SY, Bredella MA, Fazeli PK, et al. 2015 Region-specific variation in the properties of skeletal adipocytes reveals regulated and constitutive marrow adipose tissues. Nature Communications 6 7808. (doi:10.1038/ncomms8808)

Schwartz AV, Sigurdsson S, Hue TF, Lang TF, Harris TB, Rosen CJ, Vittinghoff E, Siggeirsdottir K, Sigurdsson G, Oskarsdottir D, et al. 2013 Vertebral bone marrow fat associated with lower trabecular BMD and prevalent vertebral fracture in older adults. Journal of Clinical Endocrinology and Metabolism 98 2294-2300. (doi:10.1210/ jc.2012-3949)

Shi Y, Yadav VK, Suda N, Liu XS, Guo XE, Myers MG Jr \& Karsenty G 2008 Dissociation of the neuronal regulation of bone mass and energy metabolism by leptin in vivo. PNAS 105 20529-20533. (doi:10.1073/pnas.0808701106)

Steppan CM, Crawford DT, Chidsey-Frink KL, Ke H \& Swick AG 2000 Leptin is a potent stimulator of bone growth in ob/ob mice. Regulatory Peptides 92 73-78. (doi:10.1016/S0167-0115(00)00152-X)

Stunes AK, Westbroek I, Gordeladze JO, Gustafsson BI, Reseland JE \& Syversen U 2012 Systemic leptin administration in supraphysiological doses maintains bone mineral density and mechanical strength despite significant weight loss. Endocrinology 153 2245-2253. (doi:10.1210/en.2011-1848)

Surwit RS, Edwards CL, Murthy S \& Petro AE 2000 Transient effects of long-term leptin supplementation in the prevention of dietinduced obesity in mice. Diabetes 49 1203-1208. (doi:10.2337/ diabetes.49.7.1203)

Syed FA, Oursler MJ, Hefferanm TE, Peterson JM, Riggs BL \& Khosla S 2008 Effects of estrogen therapy on bone marrow adipocytes in postmenopausal osteoporotic women. Osteoporosis International 19 1323-1330. (doi:10.1007/s00198-008-0574-6) 
Takeda S, Elefteriou F, Levasseur R, Liu X, Zhao L, Parker KL, Armstrong D, Ducy P \& Karsenty G 2002 Leptin regulates bone formation via the sympathetic nervous system. Cell 111 305-317. (doi:10.1016/S0092-8674(02)01049-8)

Tatsumi S, Ito M, Asaba Y, Tsutsumi K \& Ikeda K 2008 Life-long caloric restriction reveals biphasic and dimorphic effects on bone metabolism in rodents. Endocrinology 149 634-641. (doi:10.1210/ en.2007-1089)

Thomas T, Gori F, Khosla S, Jensen MD, Burguera B \& Riggs BL 1999 Leptin acts on human marrow stromal cells to enhance differentiation to osteoblasts and to inhibit differentiation to adipocytes. Endocrinology 140 1630-1638. (doi:10.1210/ endo.140.4.6637)

Trudel G, Payne M, Madler B, Ramachandran N, Lecompte M, Wade C, Biolo G, Blanc S, Hughson R, Bear L, et al. 2009 Bone marrow fat accumulation after 60 days of bed rest persisted 1 year after activities were resumed along with hemopoietic stimulation: the Women International Space Simulation for Exploration study. Journal of Applied Physiology 107 540-548. (doi:10.1152/japplphysiol.91530.2008)

Tuljapurkar SR, McGuire TR, Brusnahan SK, Jackson JD, Garvin KL, Kessinger MA, Lane JT, BJ O'Kane \& Sharp JG 2011 Changes in human bone marrow fat content associated with changes in hematopoietic stem cell numbers and cytokine levels with aging. Journal of Anatomy 219 574-581. (doi:10.1111/j.14697580.2011.01423.x)

Turello R, Snyder D \& Hartman HA 1984 A modification the ssmium tetroxide post-fixation technique for the demonstration of extracellular lipid in paraffin-embedded tissue sections. Journal of Histotechnology 7 75-77. (doi:10.1179/his.1984.7.2.75)

Turner RT, Kalra SP, Wong CP, Philbrick KA, Lindenmaier LB, Boghossian S \& Iwaniec UT 2013 Peripheral leptin regulates bone formation. Journal of Bone and Mineral Research 28 22-34. (doi:10.1002/jbmr.1734)

Welt CK, Chan JL, Bullen J, Murphy R, Smith P, DePaoli AM, Karalis A \& Mantzoros CS 2004 Recombinant human leptin in women with hypothalamic amenorrhea. New England Journal of Medicine 351 987-997. (doi:10.1056/NEJMoa040388)

Yeung DK, Griffith JF, Antonio GE, Lee FK, Woo J \& Leung PC 2005 Osteoporosis is associated with increased marrow fat content and decreased marrow fat unsaturation: a proton MR spectroscopy study. Journal of Magnetic Resonance Imaging 22 279-285. (doi:10.1002/ (ISSN)1522-2586)

Zhou BO, Yue R, Murphy MM, Peyer JG \& Morrison SJ 2014 Leptinreceptor-expressing mesenchymal stromal cells represent the main source of bone formed by adult bone marrow. Cell Stem Cell $\mathbf{1 5}$ 154-168. (doi:10.1016/j.stem.2014.06.008)

Received in final form 5 April 2016

Accepted 11 April 2016
(C) 2016 Society for Endocrinology Printed in Great Britain
Published by Bioscientifica Ltd. 